Philosophy and Progress: Vols. LXI-LXII, January-June, July-December, 2017 ISSN 1607-2278 (Print), DOI : https://doi.org/10.3329/pp.v61i1-2.44202

\section{RABINDRANATH TAGORE'S IDEA OF UNIVERSAL HUMANISM IN THE LIGHT OF ISLAMIC WORLD VIEW}

\author{
Ichhimuddin Sarkar
}

\begin{abstract}
Very few studies are available to understand the philosophical views of Rabindranath Tagore in the light of his attitude and realization of Islam vis-à-vis idea of universalism. Fact remains that the Islamic civilization has thoroughly been recognized in the academic circles but its depth and learning have not been studied up to expectation. European historians and philosophers seem to be hesitant to acknowledge the contribution of Islamic civilization over the centuries. Even a majority of Eastern scholars are critical about welcoming the actual merit of Islam. Rabindranath Tagore being one of the brightest stars in the galaxy of poets and writers made a serious study on the philosophy and writings of many Muslim thinkers and ultimately brought to our notice an extraordinary feeling about Islamic ideas and philosophy. Rabindranth Tagore seems to have sought the inner meaning of Islam and developed a kind of value- based attitude towards human life and the universe. It is likely that through his Gitanjali and Religion of Man (Manusher Dharma)
\end{abstract}

\footnotetext{
* Professor of History, University of North Bengal, India

E-mail : isarkar_nbu@yahoo.com
}

in particular were presented with an objective to stimulate and guide men in search of Ultimate Truth and Oneness of God. It is said that Rabindranth Tagore was acquainted with the verses of the Qur'an in his childhood and in this respect his father Maharishi Devendranath Tagore imbibed in him many theological aspects of Islam as a religion. The paper intends to explore how Tagore was influenced by Islam and as a poet-thinker he nurtured the idea of eternal truth from the Upanishads, the Tripitakas as well as the Bible and through a particular discipline and inner uplift he came to the conclusion that aggregate of essentials of diversity cannot be judged in the light of mere logic and arguments. This feeling seems to have prompted Tagore to find out the inner truth of the universe and side by side to propagate the idea of universal humanism throughout the world.

Keywords: Eternal Religion, Super human being, Value-based attitude toward human life, light of divine majesty, existence of the Almighty, beauty of nature and its calmness, harmony, Shantam, Shivam, Advaitam, feeling of love, global solidarity of all man.

Idea or faith makes a man what exactly he himself is meant for or stands for. He may be an idealist, agnostic or materialist but his convictions are fairly reflected in his personal life and social philosophy. In this respect Rabindranath Tagore was not an exception. In fact he has so far been studied from diverse angles but his religious ideas and philosophy, his introspection and realization cannot be understood fully unless they are judged through a process of evolution. We are well aware of the fact that he began his life as a follower of Adhi Brahmo Samaj, passed through a syncretistic faith in religion and eventually stopped at the stage of Religion of Man (Manusher Dharma). (Chaudhuri, 1961, pp. 144-152) He could realize futile customs and practices and at length comprehended Eternal Religion (Shashwata Dharma) of heart that bears greater truth than society. In this respect, what he believed was that the value of man as a moral and spiritual subject gains significance in Humanism. In his 
perception, God or the Creator is to be sought not in the Temples or Mosques or Churches or even in the Gurudwaras but in humanity itself. What one may find in the Vedantic concept of divinity in man is nothing but an idea popularly known as naranarayana. This perhaps may be the eternal truth of his philosophy enshrined in the 'Religion of Man'. For that reason he could see mahamanava or super human being in every individual who was manifested to him in a symphony of the 'finite' and the 'infinite' and in this context very likely he was inclined to write "Thou hast made me endless, such is thy pleasure. This frail vessel thou emptiest again and again, and fillest it ever with fresh life." (Tagore R. , Gitanjali, 1980 (Reprint), p. 1)

Keeping in mind the above mentioned philosophical view of Rabindranath Tagore we may try to understand him in the light of his attitude and realization of Islam, Islamic philosophy vis-a-vis idea of universalism. It is a fact that the Islamic civilization has thoroughly been recognized in the academic circles but the depth of infiltration of Islamic philosophy and learning has not been very easily available. European historians and thinkers have ever been in hesitation to acknowledge the contribution of Islam to the world civilization. Even a majority of Eastern scholars are no less critical about welcoming the actual merit of Islam. Rabindranath Tagore being one of the brightest stars in the galaxy of poets, writers and thinkers of the world, made a serious study on the philosophy and writings of many outstanding personalities namely Sufi poet Rumi, Hafiz, Jami, and Sa'adi which ultimately seems to have created an extra ordinary consciousness in him about the individuality and greatness of the Almighty God i.e. 'the Creator of the Universe'. The inner meaning of the Sufi literature definitely reawakened him a self-consciousness and value-based attitude towards human life and the universe. He was gradually embedded with the ideology of Islam and the symptoms could be seen from his childhood. In the background, of course, he had his grandfather Dwarakanath Tagore and his father Debendranath Tagore who were well versed in Arabic and Persian literature and all the more worshiped 'One God' having likely been impressed by the Quranic philosophy and the religious tradition propounded by Prophet Mohammed (pbuh). ${ }^{1}$

If one is to think about the philosophical value of the Gitanjali it appears that the real objective of the Noble Laureate was to stimulate and guide men in search of 'Ultimate Truth' and 'Oneness of God' (ekmebadwityam). There is a popular saying that Tagore's father Debendranath Tagore used to recite verses of the holy Quran very often and he got acquainted with Hafiz, a great poet of Persia and Tagore has himself admitted that he was intoxicated with Hafiz's verses. He wrote "when I was a boy I often used to listen to the recitation of those poems, and he translated them to me with fervour of enjoyment that touched my heart." (Tagore R., 2006, p. 282) Tagore has also admired his father as a scholar and he wondered how his father "cherished a synthesis of Hafiz and the Upanishadas in his heart." (Tagore R., 2006, p. 32) Coincidentally, Tagore's family was imbued with the invaluable spirit of sufism and very likely "Tagore's attitude and approach to life and his conception of the religion of man was essentially human, secular." (Ray, 1967, p.364)

Incidentally Tagore made an 'intellectual journey' to Iran and Iraq in April, 1932 and virtually his visit was "turned out to be the encounter with Sa'adi and Hafiz in their home town of Shiraz." (Bose, A Hundred Horizons- The Indian Ocean in the Age of Global Empire, 2006, p. 262) How was Tagore influenced by the value-based life and their culture of the Persians may be clear from his account stated in his essay 
Parashya (in Persia) where he seems to have been influenced by a dialogue with a Bedouin chief who explained Islamic universal humanity and thereby Tagore was touched by the philosophy of Islam. (Tagore R., pp. 499-502) ${ }^{2}$ It may be interesting to note that Tagore was also very much moved by the ideas of Jalal-ud-din Rumi who talked about "Nur- $i$ Muhammadi, which according to him was created from the Light of Divine Majesty." (Rumi, 2003, p. 4) That the idea of this Light of Divine Majesty i. e., Divine Eternal Light was perceived by Tagore himself has been nicely expressed nowhere than in the Gitanjali where he wrote "My world will light its hundred different lamps/ with thy flame and place them before/ the alter of thy temple." (Tagore R., 1980 (Reprint), p. 333) In the same poem he wrote "Delivarance is not for me in renunciation. I feel the embrace of freedom in a thousand bonds of delight." (Tagore R., 1980(Reprint), p. 333)

Rabindranath Tagore was a poet but above all a thinker of this universe from various perspectives. He had the calibre to write Crescent Moon, Chitra, Sadhana, Fruit Gathering, The Post Office, Hungry Stone and many other stories, novels and book of poems. But his excellent work was definitely Gitanjali (Song Offerings) which brought him international reputation and recognition as a poet-philosopher during his life time. He was awarded Nobel Prize in literature in 1913 and in the same year the Calcutta University conferred on him the degree of Doctor of Literature (D.Litt.) for his outstanding contribution in the field of literature. In February 1940, an honorary degree of Honours was given to him by the Oxford University. All these degrees and honour were offered to him as recognition for his profound scholarship, wisdom and creativity. It may not be strange to note that the Gitanjali happens to be a fine piece of literature replete with spiritual and sufistic ideas borrowed in many ways from the Upanishadas, the Quran, the Tripitaka, the Bible, and even from the Guru Grantha Saheb and various texts written by many authors of Indian tradition and beyond.

Whatever appears as the eternal value of the Gitanjali is that Tagore's belief system was nurtured in a particular point where God or Almighty is to be taken as the sustainer and upholder of life which may be taken as a Quranic concept of Rabubiyat and Samadiyat and ceaseless discipline and inner uplift. In another sayings, it may sound similar to the concept of Tawakkul (dependence) on the Almighty i.e., God is the one and unique being. To put it again in another sense $\mathrm{He}$ is the 'Aggregate of all Essences of Diversity'. But all these 'Essences' cannot be judged in the light of mere logic rather considering the substantial reality of their own. By the way this matter has not been overlooked by W. B. Yeats who in his introductory note to Gitanjali (September, 1912) wrote "Mr. Tagore, like the Indian civilization itself, has been content to discover the soul and surrender himself to its spontaneity." (Yeats, 1980, p. XVI)

It may be noted that Tagore made an extensive tour in 1916 and delivered a series of lectures and had interactions with the leading thinkers of that time and thereby drew the attention of people of North America and elsewhere. As to the spiritual unity as a condition of the survival of mankind, he condemned ultra-nationalism of the East and the West and ultimately he delivered Hibbert lectures in March, 1930 at the Manchester College, Oxford. According to S. Radhakrishnan, through these lectures, "he (Rabindranath Tagore) emphasized the validity of the ancient wisdom of India." (Radhakrishnan, 1961, p. VIII) About the content of these lectures Radhakrishnan found some fundamental idea of Rabindranath that he cultivated and Radhakrishnan summarized the essence in the words what Tagore had to mean the term 'Religion'. To quote Radhakrishnan, Tagore is said to have delivered "my 
religion is in the reconciliation of the supper-personal man, the universal human spirit, in my own individual being." (Radhakrishnan, 1961) This particular idea of Tagore was taken by Radhakrishnan as that Tagore wanted to teach us 'a religion of love and humanity and laughter.' (Radhakrishnan, 1961) In the Religion of Man, Tagore tried to bring out that "whatever name may be given to the Doctrine of Reality, it has found its highest place in the history of our religion owing to its human character giving meaning to the idea of sin and sanctity, and offering an internal background to all the ideals of perfection which have their harmony within man's own nature." (Anand, 1988, p. 84) In the Religion of Man Tagore reminded the 'Great Spirit' in which a man lives and thinks and also becomes a part of the Visvakarma (Master architect of the Universe). Tagore had found satisfaction in appealing to all how people at large throughout the world becoming conscious about the existence of the Almighty.

Within such a perception Tagore seems to have given a prophetic message which can be found in the holy Quran specially in the Surah Al-Fatiha where it is stated that "praise be to Allah, Lord of the worlds/Owner of the Day of Judgment/ Thee (alone) we worship; Thee (alone) we ask for help." (Pickthal, 1981, p. 5) or what one can see in the surah Al Furkan (25:59) where it is mentioned "who created the heavens and the Earth and all that is between them in six days." (Pickthal, 1981, p. 353) These type of examples are not rare in the Quran and surprisingly Rabindranath Tagore had the mind to realize the inner meaning about the mystery of this universe vis-a-vis the creation and very likely in his subconscious mind it vibrated some way or other and he reflected his feelings in his writings. In this respect one can cite how he developed his mindset in his childhood when he was brought to the initiation ceremony of Brahminhood and the Gayatri of meditation was given to him. He recalled it in his essay titled 'On Religion' and reiterated "Let me contemplate the adorable splendor of $\mathrm{Him} /$ Who created the earth, the air and the starry spheres/ And sends the power of comprehension / With our minds." (Tagore R. , 2006, p. 320) Tagore admitted that this meditation on the 'infinite being' united his mind with outer world and as if it came to him 'through the unseen and trackless channel'. (Tagore R. , 2006, p. 320) In order to be conscious of this divine injunction, Tagore wanted all human beings to follow the value of religion of man and to form a world community as Islam propounds brotherhood of the Ummah. This may be evident from the instruction of God to Mohammed (pbuh) through the Surah Saba (verse 28) where it is mentioned that "and we have not sent Thee (O Mohammed) save as a bringer of good things and a Warner unto all mankind; but most of mankind know not.' (Pickthal, 1981, p. 420). ${ }^{3}$ Here the community concept (ummah) of Islam finds its place in the philosophic mind of Tagore and he very likely sounded something as enshrined in the philosophy of Islam.

These ideas of Tagore are fairly expressed and noted in the Gitanjali and few other writings. In several works one can find Tagore's journey through life and its realization and at the same time how it can overcome all limitations. Tagore was always concerned to overcome the barriers that bind the human sense and divert his attention for the quest of truth in favour of 'Religion of Man' where the crux of religiosity lies in recognizing the value of man as a man. This has exactly been reflected in his The Religion of Man where he wrote "To this being I was responsible: for the creation in me is his as well as mine. It may be that it was the same creative Mind that is shaping the universe to its eternal idea; but in me as a person it had one of its special centres of a personal relationship growing into a deepening consciousness. I felt that I had found my 
religion at last, the religion of man in which the infinite became defined in humanity and came close to me so as to need my love and co-operation" (Tagore R. , 1931, p. 59f). ${ }^{4}$ This matter again brings us to see him how he was influenced by the teachings of the Quran. The philosophy of the Gitanjali shows that he was deeply impressed by the first surah of the Quran titled Al Fatiha (which has been mentioned earlier). It is true that this Surah deals with unity of God and His stand as the Creator, Evolver and Saviour of the universe. (Pickthal, 1981, p. 5) It is likely that he seems to have been touched by the meaning of another Surah named Ar-Rahaman ( $L V)$ which describes the beauty of nature and its calmness, harmony and peace therein. Moreover the balance and justice that prevail according to the law of nature. (Pickthal, 1981, p. 537)

Rabindranath Tagore had a vision of life and that it was something unusual and this can be seen from his warning as to the cause of destruction. This may be clear what he perceived about 'Nationalism'. In his lecture on 'Nationalism' he indicated about the danger of so called 'Nationalism' and crisis of humanity. In this respect he quoted the example of Japan and how Japan was following the "higher ideas of Humanity and never to follow the West in its acceptance of the organized selfishness of Nationalism as its religion, ...." (Tagore R., 1896, p. 23) This is perhaps due to his feelings as to how the concept of Nation in the European World had "thriven long upon mutilated Humanity. Man, the fairest creation of God, came out of the National manufactory in huge numbers as warmaking and money making puppets, ludicrously vain of their pitiful perfection of mechanism." (Tagore R., 1896, p. 26) This realization can be found in one of the Surahs in the Quran namely Al-Asar which states that a) Time and age are witness. b) Man is certainly in a state of ruin. c) Except those who believe in Almighty and do good works, and exhort one another to truth and enjoin one another to bear with fortitude. (Pickthal, 1981, p. 633) It may appear that Tagore believed in Anandarupam-amritam manifesting in man and nature, which is by and large reflected in the teachings of the Quran. In this context, his religion was nothing but a poet's religion and when he talked about salvation is, according to him, the internal process of perfection. In his own language "our soul must soar in the infinite and she must feel every amount that in the sense of not being able to come to the end of her attainment is her supreme joy, her final freedom." In most of his poems and songs, it is difficult to miss these spiritual value or lessons. Everywhere one can see an intimate nexus between men and God. Thus he appears to have taught people the essence of his 'Religion of Man' to lead all man to serve the human society. This temperament might have brought him to search the essence of all religions and to come to the point of 'Universal Truth' and he could find some values in Islam, which made him a proponent of Universalist aspiration. His extensive tour in the land of Sa'adi and Hafiz and particularly their home town of Shiraz brought him directly in touch with the Islamic world and there he could show himself how he was akin to the Sufi philosophy as well as the thinkers of Islam.

While writing The Philosophy of Rabindranath Tagore, S. Radhakrishnan has brought to our notice various sides of the philosophical mind of Tagore and quite interestingly mentions the influence of Christian philosophy on Tagore. (Radhakrishnan, 1961) But surprisingly, he remained silent about the same of Islam, if any, on the mind of this great poet. It is no less worth mentioning that Sugata Bose in his celebrated book (mentioned earlier) A Hundred Horizons (Indian Ocean in the Age of Global Empire) has given a vivid description of Tagore's fascination towards Islam vis a vis Sufism and in this light Rabindranath's trip to Persia (1932) 
has been described by Bose logically as "much more than a diary or a travelogue by an acquit observer of cultures." (Bose, 2006, p.261) Moreover, Sugata Bose has nicely recorded how Tagore was moved when he was near the grave yard of poet Hafiz and the "custodian of the cemetery brought out a large square volume of Hafiz's diwan (oeuvre) and asked Tagore to open it with a wish and his eyes shut."(Bose, 2006, p.263) Sugata Bose is perhaps correct when he could find out a ground of commonality in respect of culture and religion through the ideology of Rabindranath Tagore.

Whatever the idea that Tagore wanted to propagate was nothing but a social harmony with a syncretistic zeal in which he wanted to appeal to the people that "our forefathers did spread a single pure white carpet whereon the entire world was cordially invited to take its seat in amity and good fellowship. No quarrel could have arisen there; for He, in whose name the invitation went forth, for all to come, was Shantam, Shivam, Advaitam- the Peaceful, in the heart of all conflicts; the Good, who is revealed through all losses and sufferings; the One, in all diversities of creation. (Tagore, R., 2006, p. 44) Thus what Tagore wanted to popularize was an eternal truth propounded in ancient India and that was "Atmavat Sarbhutashu yah pashyati sa pashyati (i.e, He alone sees, who sees all beings as himself) (Tagore, R., 2006, p. 44) This is the idea of universalism of Rabindranath Tagore where there is no place of separatism, racism and so called religious fanaticism, or any issue that divides man from man rather brings about harmony and fellow-feeling amongst all in our human society. It is the very idea and feeling that he categorically professed through the mouth of Gora, the hero of his novel Gora (1910) in which the hero could unhesitatingly declare "today I am an Indian. There is no conflict in me in terms of Hindu, Muslim or Christian." (Tagore, 1382 (B. S.) Reprint, p. 571) Lastly we may conclude with a song by Tagore where he sang the unison of mankind and how the feeling of love becomes a treasure of joy to all;

"biswasathe yoge yethay bihara

Seikhane yog tomar sathe amaro.

Nayko bane, noy bijane, nayko amar apan mone-

Sabar yethay apan tumi he priya, sethay apan amaro.

Sabar pane yethay bahu pasara

Seikhanetei prem jagibe amaro.

Gopane prem ray na-ghare, alor mato chhadiye pade-

Sabar tumi anandadhan he priya, ananda sei amaro

(In English)

The unison with the world with which you wander,

There am I united with you.

Neither in the forest nor in solitude nor even in my own mind -

O dear where you are dear to all, you are also close to me there.

Where you stretch your hands towards all,

At that very place my love would also awake.

In secret, love does not recite inside, like light does it effulge away$\mathrm{O}$ dear you are a treasure of joy to all, that joy is mine as well.

What Tagore wanted to popularise may be that solidarity is a human instinct that is again a typical design of our mentality and a style of manifestation of the self in terms of others and vice versa. Even more the philosophy of Tagore seems to have taken much care for an endless journey for goodness and humility, which cross the narrow domestic or societal world and invite togetherness in terms of global solidarity of all men irrespective of caste, culture, religion or identity.

\section{NOTES}

1. It is said that "Tagore's father could have come across ibnArabi's concept of the 'Oneness of Being' (Wahadat-al-Wujud) and of the Perfect Man (al-insan-al-kamil). These could have kept into Tagore's thoughts from these sources, consciously or 
unconsciously. Besides this there was also the strong presence of Sufistic teachings of Islam in India. Its influence on people like Kabir, Nanak and others was also appreciated, acknowledged and accepted by Tagore." For details see Rabindranath Tagore: His Worldview, An article by Alin ur-Rahman Khan in Tagore the Eternal Seeker: Footprints of a Worls Traveller ed. by Suryakanthi Tripathi etal, New Delhi, 2015, p.332.

2. In course of conversations with Tagore the Beduin chief explained the instructions of the Prophet Mohammed (pbuh) and what he said was "Our Prophet had taught us that he is a true Muslim from whom no fellow human being fears any harm."

3. The beneficent / hath made known the Quran/ He hath created man/ He hath taught him utterance/ The Sun and the Moon are made punctual/ The stars and the trees adore/ And the sky He hath uplifted: and He hath set the measure/ That ye exceed not the measure/ But observe the measure strictly, nor fall short thereof/ And the Earth hath He appointed for (His) creatures/ Wherein are fruit and sheathed palm- trees/ Husked grain and scented herb/ Which is it, of the favors of your Lord, that ye deny ? ....

4. It may be noted that Rabindranath Tagore delivered the Hibbert lectures at the University of Oxford in 1913. The lectures were published in 1931 as The Religion of Man.

\section{References \& Bibliography}

Anand, M. R. (1988), Tagore's Religion of Man: An Essay on Rabindranath Tagore's Humanism. In B. C. Subramanyah, Rabindranath Tagore and the Challenges of Today (p. 84). Shimla.

Bose, S. (2006), New Delhi.

Bose, S. (2006), A Hundred Horizons- The Indian Ocean in the Age of Global Empire. New Delhi: Permanent Black.

Chaudhuri, B. (1961), The Poet's Religion. In C. B.M., Homage to Rabindranath Tagore (pp. 144-152), Kharagpur: K.C. Chakraborty.
Pickthal, M. (1981), The Meaning of the Glorious Koran. Delhi.

Radhakrishnan, S. (1961), The Philosophy of Rabindranath Tagore. Baroda.

Ray, N. R. (1967), An Artist in Life. Trivandrum: University of Kerala. Ray, N. R. (1967), An Artist in Life. Trivandrum: University of Kerala. Rumi, J. (2003), The Mathnawi. New Delhi.

Tagore. (1382 (B.S.) Reprint), Rabindra Rachanabali Vol. VI. Visvabharati.

Tagore, R. (1980 (Reprint)), Gitanjali. New Delhi: The Macmillan Company of India.

Tagore, R. (1980(Reprint)), Gitanjali. Delhi: The Macmillan Company of India Ltd.

Tagore, R. (2006), My Life in my Words. In U. Dasgupta. New Delhi: Penguin.

Tagore, R. (2006), My Life in My Words. New Delhi: Penguin Books.

Tagore, R. (2006), My Life in My Words. New Delhi: Penguin Books.

Tagore, R. (1896), Nationalism. Calcutta: Macmillan Pocket Tagore Edition.

Tagore, R. (n.d.), Parashya. Rabindra Rachanabal, Vol.XXII , 499-502.

Tagore, R. (1988), The Centre of Indian Culture. Visvabharati.

Tagore, R. (2006), The Centre of Indian Culture. New Delhi: Visvabharati.

Tagore, R. (1931), The Religion of Man.

Yeats, W. (1980), Gitanjali. New Delhi: The Macmillan Company of Indai Ltd. 